\title{
Aid, Dutch Disease, and Manufacturing Growth
}

\section{Raghuram G. Rajan and Arvind Subramanian}

\begin{abstract}
We examine the effects of aid on the growth of manufacturing, using a methodology that exploits the variation within countries and across manufacturing sectors, and corrects for possible reverse causality. We find that aid inflows have systematic adverse effects on a country's competitiveness, as reflected in the lower relative growth rate of exportable industries. We provide some evidence suggesting that the channel for these effects is the real exchange rate appreciation caused by aid inflows. We conjecture that this may explain, in part, why it is hard to find robust evidence that foreign aid helps countries grow.
\end{abstract}




\title{
Aid, Dutch Disease, and Manufacturing Growth
}

\author{
Raghuram G. Rajan and Arvind Subramanian
}

December 2009

(forthcoming in the Journal of Development Economics)

We are grateful for helpful comments from Chris Adam, Andy Berg, Jagdish Bhagwati, Abdoulaye Bio-Tchané, Aleš Bulíř, Nancy Birdsall, Francois Bourguignon, Ajay Chhibber, Michael Clemens, Tito Cordella, Shanta Devarajan, Alan Gelb, Ed Glaeser, Tim Harford, John Hicklin, Nurul Islam, Simon Johnson, Aart Kraay, Pravin Krishna, Anne Krueger, Ted Miguel, Michael Nowak, Jonathan Ostry, Rohini Pandey, Alessandro Prati, Lant Pritchett, Rodney Ramcharan, Dani Rodrik, David Roodman, Shankar Satyanath, T.N. Srinivasan, Quy Toan-Do, Thierry Tressel, Alan Winters, and participants at the Center for Global Development Seminar in Washington D.C., and at seminars at the International Monetary Fund, Harvard, and George Mason Universities, and the University of California at Berkeley.

We would also like to thank Gordon Hanson and four anonymous referees for extremely helpful suggestions. Manzoor Gill, Naomi Griffin, Marko Klasnja, and Ioannis Tokatlidis provided superb research assistance.

Raghuram G. Rajan and Arvind Subramanian. 2009. "Aid, Dutch Disease, and Manufacturing Growth.” CGD Working Paper 196. Washington, D.C.: Center for Global Development. http://www.cgdev.org/content/publications/detail/1423404

Center for Global Development 1800 Massachusetts Ave., NW Washington, DC 20036

202.416.4000

(f) 202.416 .4050

www.cgdev.org
The Center for Global Development is an independent, nonprofit policy research organization dedicated to reducing global poverty and inequality and to making globalization work for the poor. Use and dissemination of this Working Paper is encouraged; however, reproduced copies may not be used for commercial purposes. Further usage is permitted under the terms of the Creative Commons License.

The views expressed in this paper are those of the author and should not be attributed to the board of directors or funders of the Center for Global Development. 


\section{INTRODUCTION}

There is a voluminous literature on the effect of foreign aid on economic growth. ${ }^{1}$ A fair summary would be that this literature does not provide robust evidence of either a positive or negative correlation between foreign aid inflows and the economic growth of poor countries. The absence of a robust positive correlation is particularly surprising since the primary purpose of most aid flows is to further the economic development of the recipient. What might explain the paucity of evidence for foreign aid propelling economic growth?

One possible answer may be that there are costs emanating from aid that offset the benefits -- which include higher levels of physical investment, better education, and health, all paid for by the resource transfer. The classic analysis of these costs goes back to the Keynes-Ohlin debates on the effects of foreign transfers (such as aid) on the real exchange rate. For the case of foreign aid, the seminal work is van Wijnbergen $(1985,1986)$ building on the work of Corden and Neary (1982) in the context of natural resource discoveries.

In a simple two-good model, increased aid will have two effects. First, aid could disproportionately be targeted at expanding non-tradable services such as construction, health care, and education for which there is substantial unmet demand. This will increase wages in that sector (given a fixed supply of skilled labor in the short run), will draw skilled labor into the non-tradable sector, and increase wages overall. Given that the international price of traded goods is fixed, the higher wage in terms of traded goods will reduce traded sector profitability, competitiveness, and lead to a decline in exports. In Corden and Neary (1982)'s terminology, this is the resource movement effect.

\footnotetext{
${ }^{1}$ Important work includes Boone (1996), Alesina and Weder (2000), Bauer (1971), Burnside and Dollar (2000), Clemens, Radelet, and Bhavnani (2004), Collier and Dollar (2002), Dalgaard, Hansen, and Tarp (2004), Easterly (2003), Easterly, Levine, and Roodman (2004), Friedman (1958), Hansen and Tarp (2001), Rajan and Subramanian (2008), Roodman (2004), Svensson (2003), and World Bank (1998).
} 
In addition, the higher wages will be spent, raising the price of non-traded goods relative to traded goods (the real exchange rate) and further hurting traded sector competitiveness. Corden and Neary (1982) would term this the spending effect.

These are short run effects. But, in principle, in the medium run, aid could simultaneously also increase the productivity and supply of non-traded goods (for example, if the aid is spent on imparting skills and expanding the availability of skilled labor), offsetting the initial spending and resource movement impacts on relative prices. The overall impact, at least in the medium run-which is the focus of this paper-cannot be predicted a priori (also see Torvik (2001)). The more aid is spent on traded goods or factors (imported capital goods, foreign consultants) and on factors that are not in limited supply (unskilled labor), the more the supply of factors and non-traded goods respond to aid inflows, and the more domestic fiscal contraction takes place, the less likely will wages and prices be bid up to an excessive degree and the less likely will the real exchange rate appreciate (see Berg et al. (2005)). Thus whether aid reduces competitiveness and shrinks the tradable goods sector by pushing up the real exchange rate is ultimately an empirical question.

A hint that aid may have costs via its impact on the tradable sector is provided in Figure 1, where we plot the log of the value added in manufacturing to GDP ratio in a country against the log of the ratio of aid received to GDP for that country for two separate dates (the late 1990s and the early 1980s, separated by about 15 years), after correcting for the country's per capita PPP GDP, per capita PPP GDP squared, and country and time fixed effects. ${ }^{2}$ As the figure suggests, the more aid a country has received, the smaller its share of

\footnotetext{
${ }^{2}$ The residuals are obtained in a panel regression where the dependent variable is log of the ratio of the share of value added in manufacturing to GDP for a country (at two dates, the late 1990s and the early 1980s, separated by about 15 years), and the explanatory variables are the country's per capita GDP, per capita GDP squared (to allow for the U-shaped relationship postulated by Kuznets), and fixed effects for the country and the time period. All variables are averages for the period 1980-85 and 1995-2000, respectively. We focus on the period after 1980 because the coverage of the World
} 
manufacturing. The coefficient estimate suggests that a 1 percentage point increase in the ratio of aid-to-GDP is associated with a reduced share of manufacturing in total GDP of about $0.2-0.3$ percentage points. ${ }^{3}$

In Figure 2 we obtain a similar negative relationship when we plot the log of the ratio of manufacturing share to the share of services against the log of aid to GDP after similar corrections. So the inflow of aid is correlated with slower manufacturing growth, and the slower growth of manufacturing relative to services.

What might explain this pattern? Assuming that services are less tradable than manufacturing (at least for the period covered by our analysis), the figures suggest that aid and the relative size of tradable sectors in an economy are negatively correlated. The focus of our paper is then on providing more persuasive evidence for the channel through which this correlation emerges; that the inflow of aid leads to a relative shrinkage of the tradable manufacturing sectors of the economy and that this shrinkage occurs through the appreciation of the recipient country's real exchange rate.

Why might this matter? For instance, a number of studies (Jones and Olken (2005) and Rodrik (2008)) have argued that the traded goods sector is the channel through which an economy absorbs best practices from abroad. The absence of these learning-by-doing spillovers, which may be critical to long run productivity growth, could be one constraint on growth. Indeed, Jones and Olken (2005) and Johnson, Ostry, and Subramanian (2006) point out that virtually all countries that have had a sustained period of growth in the post-war period have seen a large increase in their share of manufacturing and manufacturing exports.

Bank data on sectoral output increases substantially and also because the core analysis in the paper below is on the 1980s and 1990s. The sample comprises countries that had an aid received to GDP ratio greater than 1 percent or are low income countries. The relationship depicted in the graph is robust to additional controls such as the terms of trade.

${ }^{3}$ Because we include fixed effects, the association between aid and manufacturing depicted in the chart is a temporal one, that is, within countries over time rather than one between countries. 
While these studies do not establish beyond doubt that there is a line of causation from manufacturing exports to overall growth—and this paper does not address this question - the existence of such a line would explain why the positive effects of aid are so hard to discern - aid leads to a shrinkage of the tradable manufacturing sector, which has adverse effects on overall growth.

There are three notable differences between our approach and that of prior empirical work. First, the papers in the literature on the effects of aid on growth of manufacturing or of manufacturing exports employ the standard cross-country methodology. ${ }^{4}$ The key innovation in our paper is to identify the effect of aid on manufacturing growth in a within-country cross-industry context, using the methodology in Rajan and Zingales (1998). By absorbing country-specific variation in country indicators, and exploiting only the within-country across-industry variation, we go some way in addressing the specification problem that plague standard cross-country regressions - that some omitted country-specific variable might explain the observed correlation.

Second, the core of the paper aims to establish the effect of aid on the relative share of exportable sectors, and to provide evidence on the channel through which aid might have such effects. Specifically, we show that the effects of aid on relative industry growth rates seem to flow largely through the real exchange rates. In other words, we seek to establish that aid is the deep determinant, while exchange rates are the proximate transmission mechanism.

Third, countries may get more aid if they perform particularly badly so aid is clearly endogenous to growth (though less clearly linked to relative industry growth rates). We address the issue of endogeneity by using plausibly exogenous instruments for aid.

\footnotetext{
${ }^{4}$ The empirical literature on aid, exchange rates, and manufacturing includes Arellano et. al. (2004), Atingi-Ego and Sebudde (2000), Bulir and Lane (2002), Elbadawi (1999), Nyoni (1998), Prati and Tressel (2006), Vos (1998), Yano and Nugent (1999) and Younger (1992) but none of them exploits within-sector variation. A fuller description of this literature is in the online version of this paper.
} 
To preview our results, we find strong evidence that aid undermines the competitiveness of the exportable sectors. In particular, in countries that receive more aid, manufacturing industries that typically export more, and thus are more likely to be adversely affected by an appreciating real exchange rate, grow slower than manufacturing industries that typically export less.

If indeed the channel is through aid's effect on real exchange rates, we should see that: (1) aid inflows do affect exchange rates and lead to exchange rate appreciation in our sample; (2) in countries with a greater appreciation of the real exchange rate (or, more precisely, with a greater aid-induced appreciation) more exportable industries grow relatively more slowly; and (3) the independent effect of aid is somewhat attenuated when we include the extent to which the exchange rate has appreciated above the norm. We do see all these effects.

This paper is structured as follows. In section II, we outline our empirical strategy. In section III, we present our main results on the effect of aid on the relative growth of sectors whose competitiveness is most likely to be adversely hit, and establish its robustness. In section IV, we provide evidence that exchange rate overvaluation (and not other policies or institutions) is the proximate channel through which aid has an effect, and section V provides a conclusion.

\section{Aid and growth: Empirical Strategy}

The following schematic representation of the effects of aid on prices and quantities.

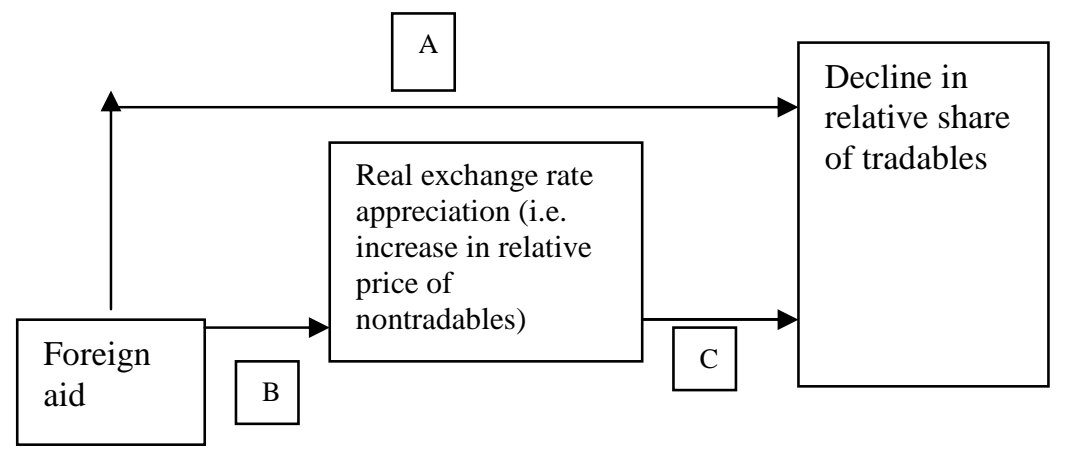


Simply put, we hypothesize a relationship from aid to the growth of the tradable sector (channel A). Channel A can in turn be broken down to two mediating channels: from aid to real exchange rates (B) and from real exchange rates to the growth of the tradable sector (C). We do not have a fully elaborated structural model that can test all these effects simultaneously so we will test for these individual relationships in the data.

We use the methodology in Rajan and Zingales (1998) to test the hypothesis that aid inflows might reduce the competitiveness of the traded goods sector. They suggest that one way to check whether a channel is at work is to see whether industries that might be most affected by a channel grow differentially (faster or slower depending on the nature of the effect) in countries where that channel is likely to be more operative. The industry characteristic we are interested in is the degree to which an industry's competitive position is affected by exchange rate appreciation, the channel is real exchange rate appreciation, and countries that get more aid are likely to be the ones where the channel is most operative. The estimation strategy is then to run regressions of the form:

Growth $_{i j}=$ Constant $+\zeta_{1 \ldots . . m} *$ Country Indicators $+\zeta_{m+1 \ldots . n} *$ Industry Indicators + $\zeta_{n+1} *$ (Industry $i$ 's share of manufacturing in country $j$ in the initial period $)+$ $\alpha$ (Aid to country $j^{*}$ Sensitivity of industry $i$ to exchange rate appreciation $)+\varepsilon_{i j}$

where Growth $\mathrm{ij}_{\mathrm{j}}$ is the annual average rate of growth of value added of industry $\mathrm{i}$ in country $\mathrm{j}$ over a ten-year period, obtained by normalizing the growth in nominal value added by the GDP deflator; $\zeta_{1 \ldots . . . m}$ are the coefficients of the country fixed effects; $\zeta_{\mathrm{m}+1 \ldots . \mathrm{n}}$ are the coefficients of the industry fixed effects; $\zeta_{n+1}$ is the coefficient of the initial period share of industry $\mathrm{i}$ in total value added in country $\mathrm{j}$ (which controls for convergence-type effects); Aid to country $\mathrm{j}$ is the average aid to GDP ratio for that country over the sample period. The coefficient of interest for us is $\alpha$. It captures an interaction between a country-specific aid 
variable and an industry's sensitivity to the exchange rate effects induced by foreign aid. We posit that countries that receive more aid should see a more negative impact in industrial sectors that are more sensitive, so that we would expect the coefficient $\alpha$ to be negative.

The chief advantage of this strategy is that by controlling for country and industry fixed effects, the problem of omitted variables bias or model specification, which seriously afflicts cross-country regressions, is diminished. Essentially, we are making predictions about within-country differences between industries based on an interaction between a country and industry characteristic. Moreover, because we focus on differences between manufacturing industries (rather than between, say, manufacturing and services industries), we can rule out factors that would keep manufacturing underdeveloped as explanations of our results - for these factors should not affect the differences between manufacturing industries.

\section{A. Implementing the Strategy}

However, this focus on manufacturing only (driven also by data availability) comes at a cost. The manufacturing sector, by and large, is tradable. So how do we develop a proxy for the sensitivity, or relative sensitivity, of an industry to the competitiveness effects of aid?

One approach is to recognize that in a poor developing country, the lack of competitiveness is likely to show up to a greater extent in exports, than in import-competing industries. This is in part because, during the time-period under study, in a poor country with an overvalued exchange rate, government actions to support import-competing industries (for example, through import tariffs and non-tariff barriers) were easier than actions to support exporting industries (for example, through cash or tax subsidies). Our proxy for exportability is an indicator variable for each industry, which takes the value 1 if the industry has a ratio of exports to value added (averaged across all countries in the sample) greater than the median 
across industries. ${ }^{5}$ The indicator takes the value zero otherwise. We call this indicator "exportability1."6 We use another measure of exportability, which is simply a dummy equal to one for the four industries that have been most closely associated with the growth of developing countries as they have moved out of agriculture: textiles, clothing, leather, and footwear.

Of course, not all exports are likely to be subject to adverse effects from aid. In particular, exports of extractable resources where labor intensity is low are unlikely to be affected by an overvalued real exchange rate. Fortunately, by focusing on manufacturing, we largely exclude such industries.

Because we examine growth differentials between industries within countries, the results are less sensitive to the rationale for why aid is given. For example, even if aid is given only to countries that display poor growth, inter-industry growth differentials should not be seriously affected. So, in our core specification, we will report our results using a simple OLS estimation strategy. However, there can be a potential, if indirect, problem of reverse causality. Suppose low growth is primarily because countries have overvalued exchange rates, and aid is systematically given to countries that have more overvalued exchange rates. In this case, we might be attributing to aid what is actually driven by trade and exchange rate policies. One way to address this is to correct directly for policies, which we attempt to do. Another is through instrumentation, which allows us to disentangle the direction of causality. We will, therefore, also show that our results are robust to instrumentation. Our instrumentation strategy, which draws directly from Rajan and Subramanian (2008), is described in the Appendix.

\footnotetext{
${ }^{5}$ We obtained these data from Nicita and Olarrega (2001).

${ }^{6}$ By discretizing our index we lose some information, but we also eliminate noise in classification. We also stay closer to the notion that either a product is exportable or it is not.
} 


\section{B. Data and their Sources}

The data and sources are described in detail in Appendix 1. The data for industry value added growth comes from the Industrial Statistics Database (2003) of the United Nations Industrial Development Organization (UNIDO). The data are at the 3-digit level of the International Standard Industrial Classification of All Economic Activities (ISIC, Revision 2) and are available for the 1980s and 1990s.

In order to keep the sample as large as possible without compromising our focus on long-term growth, we include all those industry observations where the average growth rate can be computed over at least a seven-year period in the decade. On this criterion, the UNIDO database has data for 47 developing countries for the 1980s and 31 countries for the 1990s.

But our methodology is most applicable when we include broadly similar countries with roughly similar levels of technological endowments. At the same time, we do not want to exclude recipients of significant aid. Our final sample therefore comprises countries that receive aid greater than 1 percent of GDP or are low-income countries according to World Bank definitions in the initial year of the sample. Our sample then has 32 countries for the 1980s and 15 countries for the 1990s. The UNIDO database contains data on 28 industries in these countries. $^{7}$

In Table 1, we present means, medians, and standard deviations for the key variables in the analysis. The median growth rate of value added for industries is 1.7 percent for the decade 1980-90 and 3.7 percent for 1990-2000. The average aid inflow into the 32 countries in the 1980-1990 sample is 5.3 percent of GDP and the average aid inflow into the 15

\footnotetext{
${ }^{7}$ Appendix 1 lists all countries for which data were available as well as those countries that were included in the econometric analysis.
} 
countries in the 1990-2000 sample is 4.7 percent of GDP. In much of the paper we will focus on the results for the 1980s because our sample is twice as large (32 countries and 684 observations) as it is for the 1990s (15 countries and 357 observations). We will only present some key results for the 1990s, and refer the reader to the working paper version for robustness checks.

Some additional concerns need to be discussed. First, given that a number of countries are not covered by the UNIDO database, the concern arises whether the countries in our sample differ from the typical aid recipient. Comparing the core 1980s sample that we use in this paper with a larger sample (comprising all countries selected on the same criteria as in this paper and for which manufacturing data are available in the World Bank's World Development Indicators), we find countries in our sample receive moderately less aid (5.6\% relative to $7.0 \%$ ) and grow somewhat faster (GDP growth $1.0 \%$ vs $0.7 \%$, manufacturing growth $4.8 \%$ vs $3.6 \%$ ). Countries in our sample are neither considerably worse in performance, nor indeed very different from the larger sample. The variation in our sample on these indicators is also not very different (see Appendix Table 1D). Prima facie, there is no clear evidence that our sample is "special."

A second potential concern, related to the above, is that only a few countries in our sample have significant manufacturing sectors, limiting the relevance of our analysis. On this, it is worth pointing out that the share of manufacturing in GDP in our sample is not very different from the larger set of developing countries that receive aid greater than 1 percent of GDP (see row 3 in Appendix Table 1D). In other words, it is possible that, and indeed this is what our core results purport to establish, this low share is a consequence of aid. Thus, low manufacturing share is not in itself a reason not to explore the impact of aid, although it is clearly relevant when evaluating claims about the overall growth impact of aid. We will, however, undertake some robustness tests to address this concern. 


\section{Aid And Sensitivity to ExChange Rate ApPreciation}

\section{A. The Core Specification}

We present our core specifications in Table 2 for the 1980s and 1990s corresponding to the relationship depicted as channel A in the schema in Section II.A. The dependent variable is the annual average growth in value added in industry $i$ in country $j$. We estimate the coefficient of the interaction between exportability and aid. The four columns correspond to our two measures of exportability for the 1980s and 1990s sample. In all four cases, the interaction term is negative and statistically significant at the 5 percent confidence level or above. Value added in exportable industries grows relatively more slowly than for other industries in countries that receive more aid.

What can we say about magnitudes? The estimate in column suggests that in countries that receive an extra 1 percentage point of aid, exportable industries (as defined by the exportability1 index) grow slower by about 0.5 percentage point per annum relative to non-exportable industries. The estimate in column 2 suggests that clothing and footwear sectors grow slower by about 1 percentage point a year relative to other industries in countries that receive 1 percentage point of GDP more in aid. This is quite substantial when compared with the average growth rate in the sample of 1.8 percent. The estimated magnitudes are slightly larger for the 1990s.

We depict this core result for the 1980s in a non-parametric form in Chart 3. We divide the industries into two groups (above- and below-median) depending on their exportability. Next we estimate for each country the difference in average growth in annual value added between above-median and below-median exportable industries. We plot this difference against the aid-to-GDP received by each country. Chart 3 shows that the 
difference in growth is negatively related to the aid received by a country, and no single country drives it.

\section{B. Robustness to Instrumentation}

As we said earlier, there is no obvious reason to expect growth in particular industries to drive aid or to determine the inherent exportability of industries. However, there can be a potential, if indirect, problem of reverse causality. Suppose low growth is primarily because countries have overvalued exchange rates, and aid is systematically given to countries that have more overvalued exchange rates. In this case, we might be attributing to aid what is actually driven by trade and exchange rate policies. So, we check if our results are robust to instrumentation, using the instrument we developed in Rajan and Subramanian (2008).

The key idea for instrumentation in Rajan and Subramanian (2008) is to model the supply of aid based on donor-related rather than recipient-specific characteristics. In other words, we base our instrument on considerations that drive individual donors to give aid to a country other than those related to a country's level of income or growth. So, our construction of instruments starts from the bilateral donor-recipient relationship - including measures like colonial ties, common language, and relative size to predict bilateral aid flows -- and this is then aggregated up to calculate predicted aid (as Frankel and Romer (1999) have done in the trade literature). This is in contrast to the literature that picks instruments directly at the level of the recipient country.

The results are presented in Table 3, columns 1 and 2. The second-stage results for the interaction terms are in Panel A, with the corresponding first-stage in Panel B. ${ }^{8}$ The coefficient on the interaction term continues to be significant, and the magnitudes of these

\footnotetext{
${ }^{8}$ In this table, the standard errors in the second-stage regressions are corrected to take account of the fact that the instrument used in the first-stage is estimated. We used the procedure in Frankel and Romer (1999) to do this correction.
} 
coefficients are greater than the OLS estimates. The results in Panel B show that there is no problem of weak instrumentation because the F-value for the instrument is above 50 in all columns, which comfortably exceeds the Staiger-Stock (1997) threshold of 10 for strong instruments. ${ }^{9}$

One concern might be that the countries in our base regression include ones with tiny manufacturing sectors, which may skew the results. As a check that this does not drive our results, we include only countries that had a manufacturing to GDP share greater than $15 \%$. In Table 3, columns 3 and 4, we find the coefficient estimates for this narrower sample to also be statistically and economically significant.

Another concern is that the historical and colonial ties in our instrument might proxy for the quality of a country's institutions. From ICRGE (International Country Risk Guide), we obtain a measure of the quality of government institutions that affect property rights or the ability to conduct business. We then control for institutional quality (interacted with the exportability indicators to capture the fact that exportables may be more institution-intensive) in columns 5 and 6 . The core interaction coefficient between aid and exportability remains qualitatively similar in magnitude and significance. ${ }^{10}$

\section{The Transmission Mechanism From Aid to Sectoral GroWTH}

To summarize the results thus far, we have shown the link between aid and the relative growth of exportable industries. The theory we have laid out suggests this is because of the effect of aid on the real exchange rate, which in turn adversely affects the laborintensive and exportable industries. This then leads to the natural question: how can we be

\footnotetext{
${ }^{9}$ With one endogenous variable, the F-value for the strength of the instrument is simply the square of the t-statistic associated with its coefficient.

${ }^{10}$ In a longer version of this paper that is available online, we show that our results are robust to alternative samples, notably the exclusion of outliers, to clustering of standard errors, to alternative measures of value added growth, and to alternative measures and types of aid.
} 
sure that our core result does indeed reflect such an effect and what is the connection between aid and real appreciation? To answer these questions we can bring to bear more evidence, direct and indirect, relating to real exchange rate appreciation.

\section{A. Does Aid “Cause” Excess Appreciation?}

Before we elaborate on our results, we need to clarify the term "excess appreciation". Strictly speaking aid, via its spending effect, causes a currency appreciation which leads to a decline in exports. The problem, however, is that currency appreciation could also be a trend phenomenon associated with rising trade and incomes (the Balassa-Samuelson effect). Therefore, we want to pick up the measure of real appreciation that is over and above that suggested by the Balassa-Samuelson effect - that real exchange rates increase with real incomes. We follow Johnson, Ostry and Subramanian (2007) (and implicitly, Dollar (1992), Easterly and Levine (2003), and Rodrik (2008)) in measuring excess appreciation or overvaluation. ${ }^{11}$

In Table 4, we provide evidence that excess appreciation is the channel through which aid affects exports. In column 1, we show the simple correlation between excess appreciation and aid inflows which is statistically significant at the 1 percent level. If real appreciation is the channel, then like aid, it should particularly affect exportable sectors. In other words, in countries with more appreciated exchange rates, exportable and labor-intensive sectors should grow relatively slower than other sectors. We therefore estimate model (1) above with the difference that we replace the aid variable with our measure of excess appreciation. The results in columns 2 and 3 in Table 4 show that the interaction term between excess

\footnotetext{
${ }^{11}$ The measure of excess appreciation is based on departures from long-run PPP. For every year in the sample period, we regress over the cross-section of countries, a country's price level of GDP from the Penn World Tables (6.1) on its real GDP per capita (in PPP terms). The deviation of the actual price level from the estimated price level is a measure of the country's excess appreciation. We averaged the annual values over the 1980s and 1990s respectively to obtain the final measure of excess appreciation.
} 
appreciation and either of our exportability measures is negative and significant. The coefficient estimates suggest that a one percentage point excess appreciation reduces the annual average growth of the exportable sectors by 0.07 and 0.2 percent, respectively, for the two measures of exportability. We have checked these results are robust to replacing our measure of excess appreciation with other measures of exchange rate overvaluation, including the recent work of Rodrik (2008) and Easterly and Levine (2003) and find that the results described here hold for those measures too (available from the authors upon request).

We have just established that excess exchange rate appreciation has a similar effect as aid on the growth in value added of exportable industries. Another way to check this is to introduce both the aid and excess appreciation interactions in the same regression, which we do in columns 4 and 5 of Table 4 . If aid is indeed the deep causal determinant, and excess appreciation the main mediating channel, we should find that the direct effect of the aid interaction should be highly attenuated in the presence of the excess appreciation exportability interaction. Indeed, this is what we find. In both cases, the coefficient estimate of the excess appreciation interaction remains significant, while that for the aid interaction shrinks in both magnitude and statistical significance. This suggests that excess appreciation may represent the channel through which aid has influence. ${ }^{12}$

We offer one final piece of evidence in favor of excess appreciation as the channel, using our instrument for aid (interacted with exportability) in explaining the degree of excess appreciation (interacted with exportability) in the first stage, and use the predicted excess appreciation interaction in the second stage. The IV results for the second stage (columns 6 and 7, Panel A) suggest that the component of overvaluation caused by exogenous aid inflows does hurt competitiveness.

\footnotetext{
${ }^{12}$ We obtained very similar results when we used the Easterly and Levine (2003) measure of overvaluation.
} 


\section{B. Is the Excess appreciation a Reflection of other Policies Rather than Aid?}

Is the observed significant estimate for the exportability-aid intensity interaction a proxy for other policies than aid? Consider trade reform. It is well-known that trade reform alleviates the anti-export bias of a regime. Is it possible that countries are poor because they have bad trade policies, and this, not aid, is responsible for the pattern of industry growth we observe? Indeed, could restrictive trade policies themselves be responsible for the observed excess appreciation (see, for example, Bhagwati and Desai (1973) or Krueger (1975)) One way to test this is to include an interaction between the strength of trade liberalization policies and exportability. If the trade reform interaction swamps the aid interaction, we would have less confidence that aid causes the differential growth patterns we observe.

In Tables 5A and 5B column 1, we include the Sachs-Warner measure of trade reform interacted with the exportability measures. We find that the coefficient on the trade policy interaction is insignificant but the aid interaction is relatively unchanged in magnitude and statistical significance. In column 2, we check whether trade policy as measured by the average level of tariffs interacted with exportability has any impact on the effect of the aid interaction. The aid interaction continues to have a negative and significant coefficient. ${ }^{13}$

One could argue that exchange rate mismanagement and distortions result in slow growth, aid inflows, and the observed relative growth patterns of industries. In column 3, we use a measure of the black market premium (from Reinhart and Rogoff (2003)) instead of the trade policy measure, and obtain similar results. ${ }^{14}$ In column 4 , we introduce an interaction between macroeconomic instability (which we measure as the standard deviation of

\footnotetext{
${ }^{13}$ Tariffs are unweighted averages across all products and are obtained from the World Bank's database available (and explained in greater detail) at http://econ.worldbank.org/WBSITE/EXTERNAL/EXTDEC/EXTRESEARCH/0,,contentMDK:2105 1044 pagePK:64214825 piPK:64214943 theSitePK:469382,00.html.

${ }^{14}$ Rodriguez and Rodrik (1999) argue that both the Sachs-Warner and black market premium measures are measures not just of trade policy but of broader macroeconomic stability.
} 
consumer price inflation) and exportability. Again, the aid-exportability coefficient estimate is relatively unchanged in these two specifications. Hence, the results in columns 1-4 suggests that it is aid rather than trade or macroeconomic policies that cause exchange rate appreciation, reinforcing the message obtained from instrumentation.

The next step is to show that aid does not affect industry growth through channels other than excess appreciation. One alternative explanation of the basic interaction between exportability and aid is that industries with a high need for capital (which need not be the exportable industries) grow relatively faster as a country receives aid inflows. This would be a relatively benign explanation of our basic findings, suggesting that aid relieves financing constraints and increases the overall resource envelope. ${ }^{15}$

There are three reasons why this is an unlikely explanation. First, the evidence in the introduction suggests the manufacturing sector (which is typically more capital intensive than the services sector) is relatively smaller than the service sector in aid receiving countries, not consistent with the benign "aid is financing" explanation. Second, we have also seen the adverse effects of aid on the relative growth rates of exportable industries comes through an excess appreciation of the real exchange rate. Again, this is inconsistent with the benign explanation.

Third, if the capital-enhancing channel is at work (rather than the real-exchange-rateexcess appreciation channel), countries that receive more aid should see an increase in the output of industries that are more dependent on external financial resources. To control for any possible effect of aid in alleviating financing constraints, we include the interaction of aid inflows with the Rajan and Zingales (1998) variable that measures the dependence of a

\footnotetext{
${ }^{15}$ The simplest example of aid providing more resources to the private sector would be one where the government reduces its borrowing from the banking system in response to the aid, and hence makes more credit available to the private sector.
} 
particular industry on external resources to finance investment. Thus, if aid increases the resource envelope available to the industrial sector, we should expect the coefficient of this interaction term to be positive. Moreover, if the availability of capital rather than exportability is what matters, the coefficient on the aid-exportability interaction term should fall in magnitude when we include the aid-financial dependence interaction.

In Tables 5A and 5B, column 5, we add another term, which is the interaction of aid and financial dependence of an industry. Only the aid-exportability interaction is statistically significant (and negative). The aid-financial dependence interaction is not statistically significant. Therefore, it does not appear that the channel through which the relative growth rates are affected by aid is via capital-intensive sectors getting increased access to resources. The magnitudes of the aid-exportability interaction coefficient are broadly similar to that estimated in columns 1 and 2 of Table 2, suggesting that exportability is not an indirect proxy for resource intensity.

\section{CONCLUding Remarks}

Taken together, our results suggest there may indeed be an adverse impact of aid on the relative growth of exportable sectors, and that the channel through which these effects are felt is the exchange rate overvaluation induced by aid.

Despite the fact that for many aid-receiving countries, the manufacturing sector might be less important currently than agriculture, it is worth remembering that that was also true for many of the fast-growing countries when they first embarked upon development. Manufacturing exports provided the vehicle for their growth take-off, so any adverse effects on such exports should prima facie be a cause for concern about the effects of aid on growth.

The message from our work is that countries should avoid creating the conditions that generate uncompetitive exchange rates. To the extent that aid inflows are responsible, it 
would suggest a focus on the part of both donors and recipients on tailoring aid flows to the absorptive capacity for aid in the economy.

More generally, the theory does not suggest that the adverse effects of aid on competitiveness are inevitable, but our evidence indicates that the historical experience has not been positive. From a research perspective, it is perhaps more fruitful now to move beyond the inconclusive debate of whether aid is effective, and focus on specific ways it can be made to work better, by better understanding the reasons that might impair or enhance its effectiveness. 
Chart 1: Manufacturing and Aid between 1980 and 2000

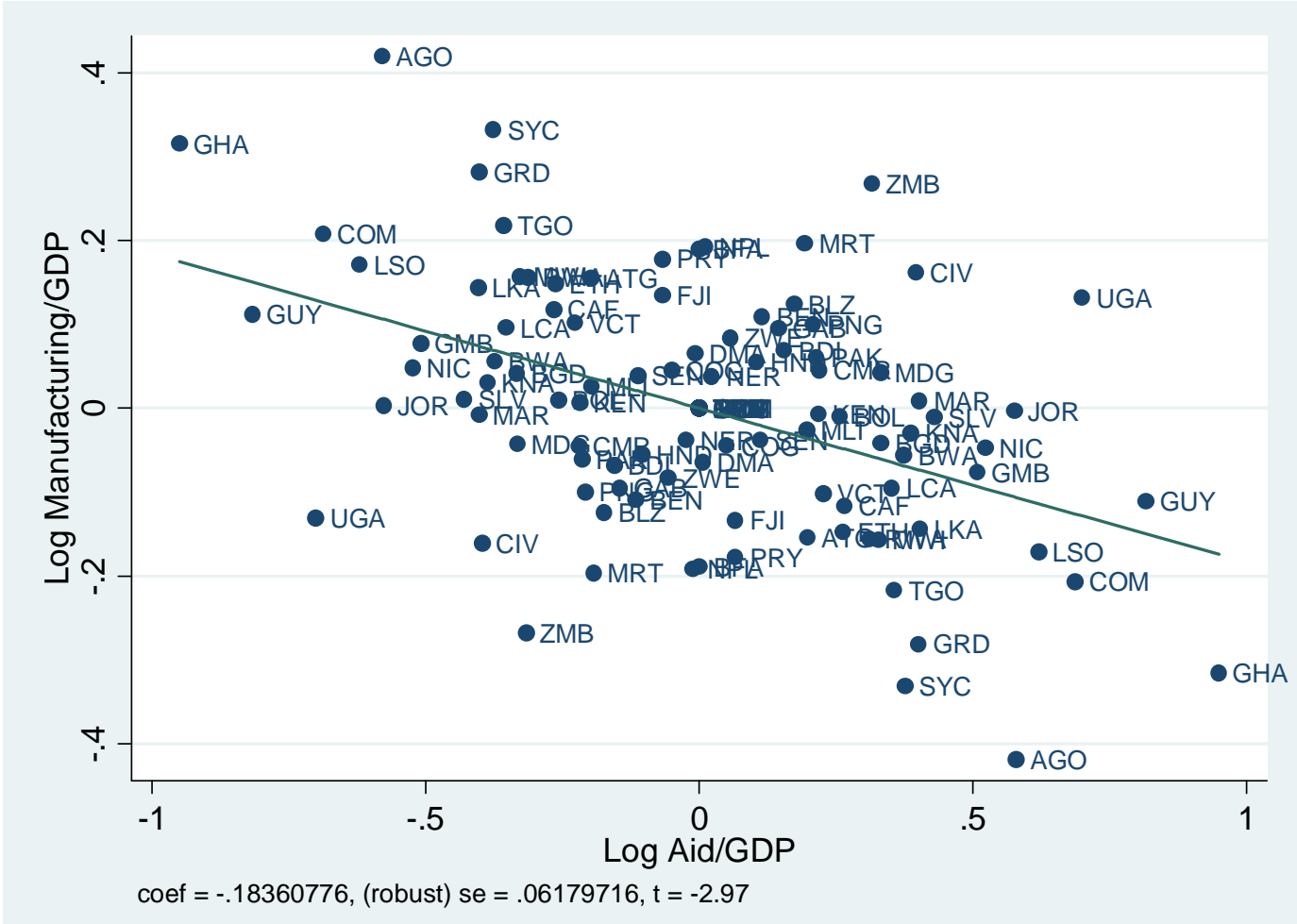

This plot is based on running a panel regression where the dependent variable is log of the ratio of the share of value added in manufacturing to GDP for a country (at two dates, the late 1990s and the early 1980s), and the explanatory variables are the country's per capita PPP GDP, per capita PPP GDP squared, and fixed effects for the country and the time period. It can be interpreted as represented the conditional relationship between the change in the size of the manufacturing sector between 1980 and 2000 in a country and the change in aid over the same period. All variables are averages for the period 1980-85 and 1995-2000, respectively. To facilitate comparability with the core results in the paper, the sample was chosen according to the same criteria as in the core the sample of the paper, namely to include countries that had an aid-to-GDP ratio greater than 1 percent or are low-income countries. Data on manufacturing are from the World Bank's World Development Indicators. 
Chart 2: Share of Manufacturing Relative to Services and Aid Between 1980 and 2000

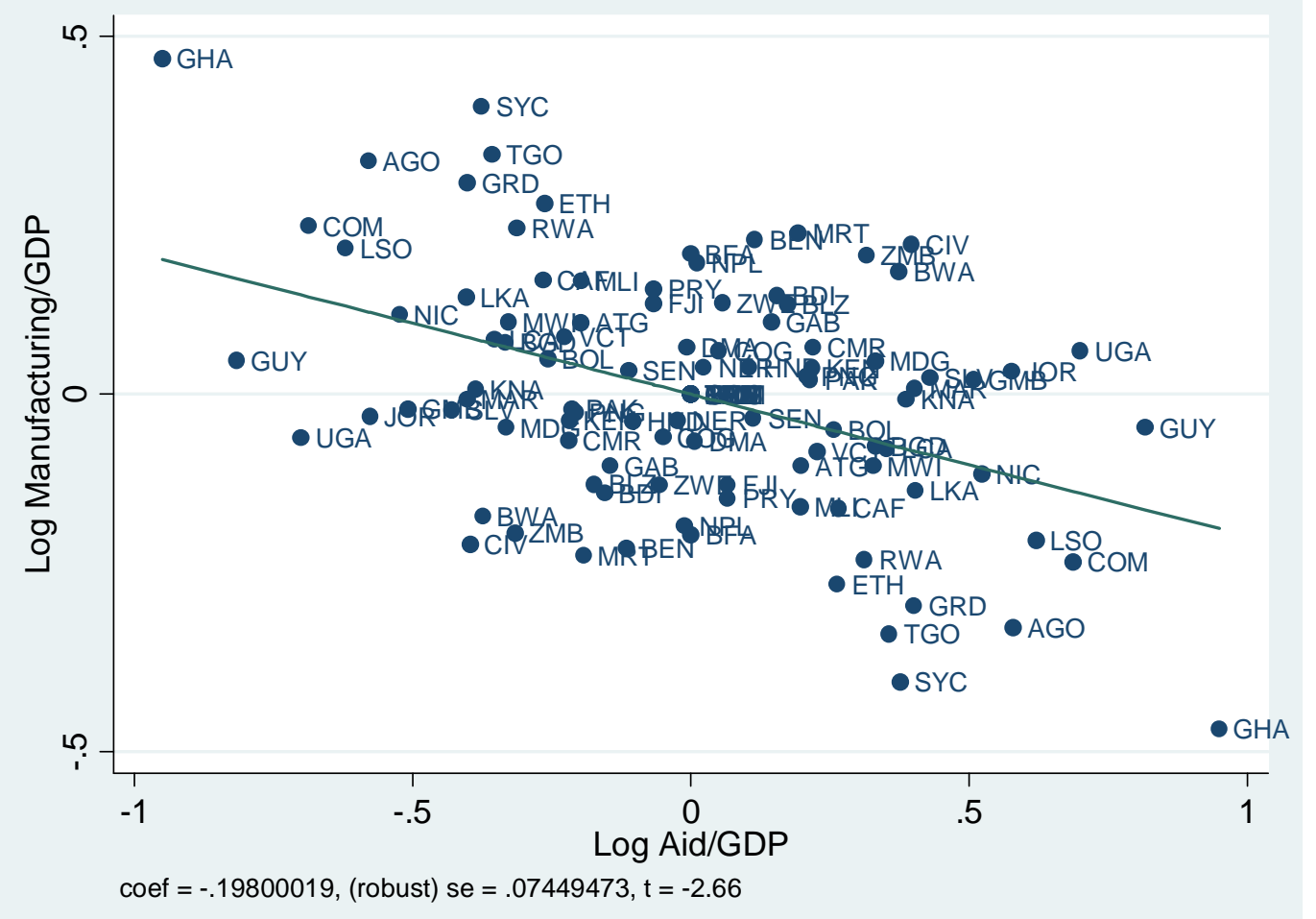

This plot represents the conditional relationship between the change in the size of the manufacturing sector relative to the size of the services sector between 1980 and 2000 in a country and the change in aid over the same period. The share of the services sector is obtained as 1-(share of agriculture + share of industry). It is based on running a panel regression where the dependent variable is $\log$ of the ratio of the share of value added in manufacturing to GDP for a country (at two dates, the late 1990s and the early 1980s), and the explanatory variables are the country's per capita PPP GDP, per capita PPP GDP squared, and fixed effects for the country and the time period. All variables are averages for the period 1980-85 and 1995-2000, respectively. To facilitate comparability with the core results in the paper, the sample was chosen according to the same criteria as in the core the sample of the paper, namely, to include countries that had an aid-to-GDP ratio greater than 1 percent or are low-income countries. Data on manufacturing and services are from the World Bank's World Development Indicators. 


\section{Chart 3: Non-Parametric Depiction of Core Results}

Panel A: Based on Exportability1 Index

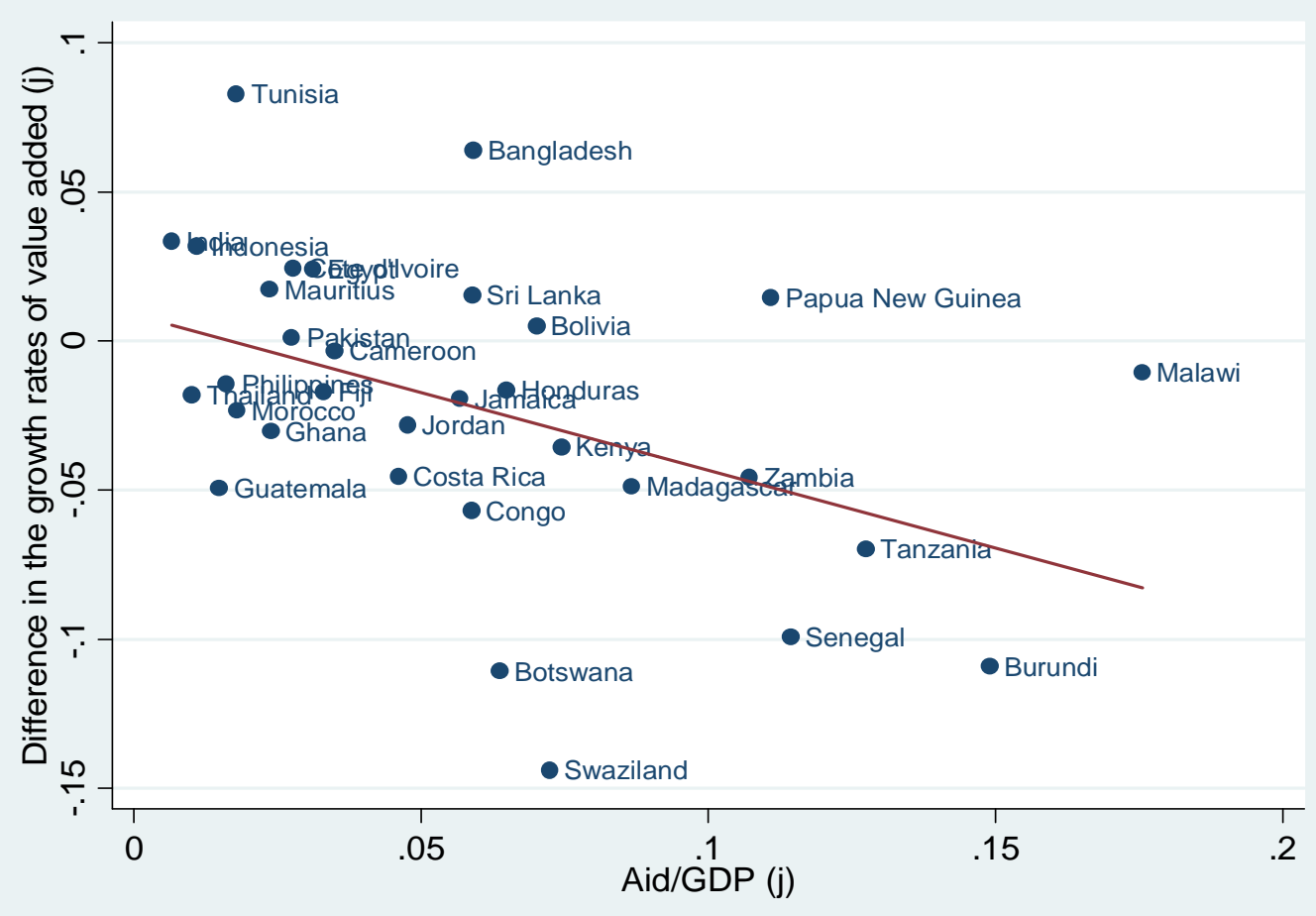

Panel B: Based on Exportability2 Index

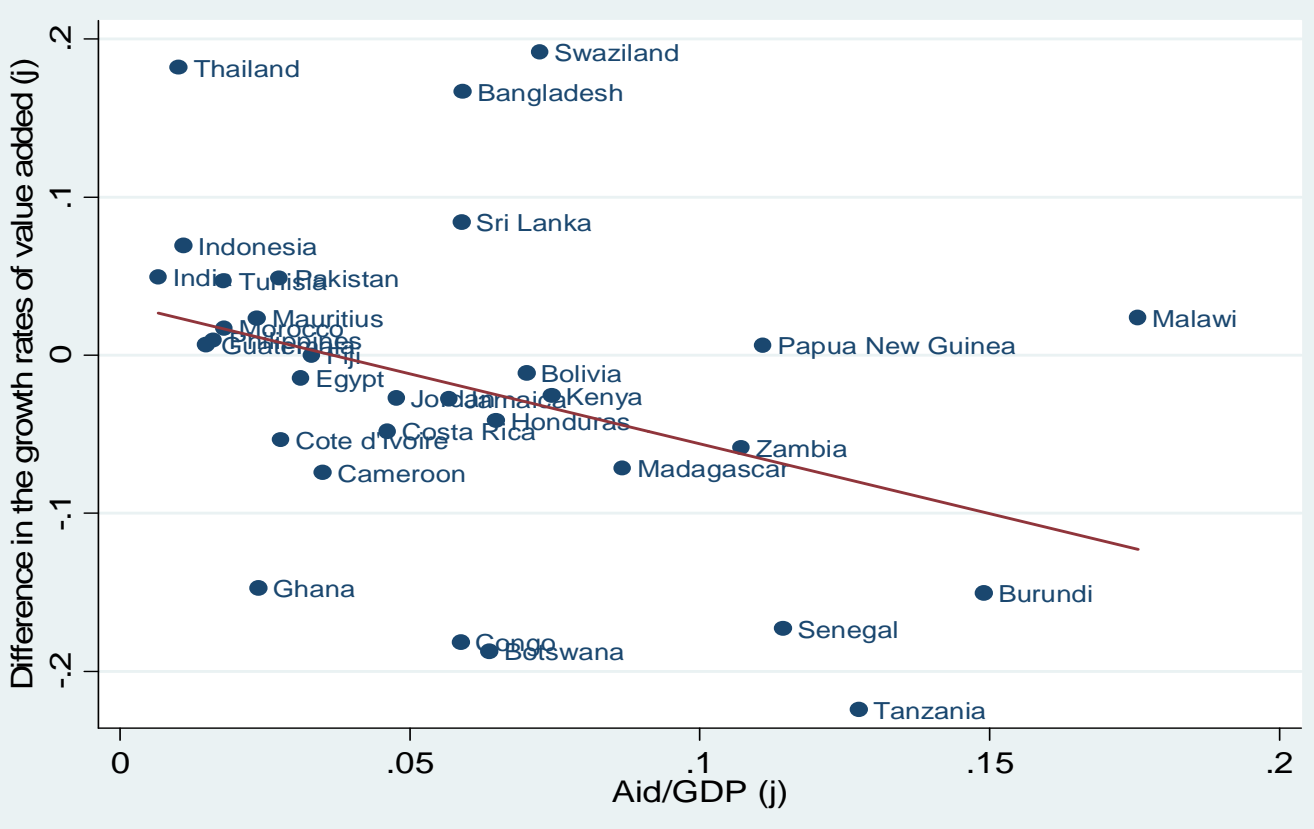

We divide the industries into two groups-exportable and others. In panel A, the exportable industries are as defined by the exportability1 index, and in panel B as defined by the exportabillity2 index. Next we estimate for each country the difference in average growth in value added between the exportable and other industries. The $\mathrm{y}$-axis measures this difference, which is plotted against the aid-to-GDP received by each country ( $\mathrm{x}$-axis). 
Table 1. Summary Statistics

\begin{tabular}{|c|c|c|c|c|c|c|c|}
\hline \multicolumn{8}{|c|}{ A. Across Countries and Industries in the Base Sample } \\
\hline Variables & Period & Mean & Median & $\begin{array}{c}\text { Standard } \\
\text { Deviation }\end{array}$ & Minimum & Maximum & $\begin{array}{c}\text { Number of } \\
\text { Observations }\end{array}$ \\
\hline \multirow[t]{2}{*}{ Growth Rate of Value Added $i j$} & $1980 \mathrm{~s}$ & 0.018 & 0.017 & 0.121 & -0.457 & 0.754 & 684 \\
\hline & $1990 \mathrm{~s}$ & 0.030 & 0.037 & 0.108 & -0.530 & 0.337 & 357 \\
\hline \multirow[t]{2}{*}{ Initial Industry Share ij } & $1980 \mathrm{~s}$ & 0.045 & 0.022 & 0.068 & 0.000 & 0.562 & 684 \\
\hline & $1990 \mathrm{~s}$ & 0.041 & 0.020 & 0.064 & 0.000 & 0.525 & 357 \\
\hline \multicolumn{8}{|c|}{ B. Across Industries in the Base Sample } \\
\hline Variables & Period & Mean & Median & $\begin{array}{c}\text { Standard } \\
\text { Deviation }\end{array}$ & Minimum & Maximum & $\begin{array}{c}\text { Number of } \\
\text { Observations }\end{array}$ \\
\hline$\overline{\text { Exportability1 Index } i}$ & $1980 \mathrm{~s}, 1990 \mathrm{~s}$ & 0.5 & 0 & 0.500 & 0 & 1 & 28 \\
\hline Exportability2 Index $i$ & 1980s, 1990s & 0.14 & 0 & 0.354 & 0 & 1 & 28 \\
\hline Financial Dependence $i$ & $1980 \mathrm{~s}$ & 0.233 & 0.219 & 0.322 & -0.451 & 1.140 & 27 \\
\hline \multicolumn{8}{|c|}{ C. Across Countries in the Base Sample } \\
\hline Variables & Period & Mean & Median & $\begin{array}{l}\text { Standard } \\
\text { Deviation }\end{array}$ & Minimum & Maximum & $\begin{array}{c}\text { Number of } \\
\text { Observations }\end{array}$ \\
\hline \multirow[t]{2}{*}{ Aid to $G D P j$} & $1980 \mathrm{~s}$ & 0.053 & 0.036 & 0.039 & 0.008 & 0.176 & 32 \\
\hline & $1990 \mathrm{~s}$ & 0.047 & 0.036 & 0.040 & 0.006 & 0.139 & 15 \\
\hline Average Real Exchange Rate & $1980 \mathrm{~s}$ & -0.077 & -0.153 & 0.355 & -0.667 & 0.664 & 31 \\
\hline Overvaluation $j$ & $1990 \mathrm{~s}$ & -0.133 & -0.011 & 0.368 & -0.721 & 0.821 & 15 \\
\hline \multirow[t]{2}{*}{ Policy (Sachs-Warner) index $j$} & $1980 \mathrm{~s}$ & 0.279 & 0.000 & 0.378 & 0.000 & 1.000 & 32 \\
\hline & $1990 \mathrm{~s}$ & 0.775 & 1.000 & 0.335 & 0.000 & 1.000 & 15 \\
\hline \multirow[t]{2}{*}{ Black Market Premium $j$} & $1980 \mathrm{~s}$ & 0.698 & 0.174 & 1.242 & -0.008 & 5.936 & 30 \\
\hline & $1990 \mathrm{~s}$ & 0.142 & 0.054 & 0.288 & 0.017 & 1.247 & 15 \\
\hline \multirow[t]{2}{*}{ Initial per Capita Income j (in log) } & $1980 \mathrm{~s}$ & 7.639 & 7.732 & 0.609 & 6.406 & 8.659 & 31 \\
\hline & $1990 \mathrm{~s}$ & 7.750 & 7.830 & 0.708 & 6.202 & 9.106 & 15 \\
\hline \multirow[t]{2}{*}{ Life Expectancy $j$} & $1980 \mathrm{~s}$ & 56.53 & 54.83 & 7.04 & 44.21 & 72.70 & 32 \\
\hline & $1990 \mathrm{~s}$ & 60.95 & 61.71 & 7.56 & 45.00 & 70.31 & 15 \\
\hline \multirow[t]{3}{*}{ Geography $j$} & $1980 \mathrm{~s}$ & -0.709 & -1.015 & 0.552 & -1.040 & 0.724 & 32 \\
\hline & $1990 \mathrm{~s}$ & -0.641 & -1.014 & 0.604 & -1.040 & 0.724 & 15 \\
\hline & $1980 \mathrm{~s}$ & 0.409 & 0.399 & 0.127 & 0.183 & 0.723 & 28 \\
\hline Institutional Quality (ICRG) index $j$ & $1990 \mathrm{~s}$ & 0.528 & 0.526 & 0.054 & 0.405 & 0.610 & 14 \\
\hline \multirow[t]{2}{*}{ Average Level of Tariffs $j$} & $1980 \mathrm{~s}$ & 33.279 & 29.000 & 22.047 & 4.000 & 97.000 & 32 \\
\hline & $1990 \mathrm{~s}$ & 23.277 & 24.000 & 8.291 & 10.000 & 45.000 & 15 \\
\hline \multirow[t]{2}{*}{ Standard Deviation of Inflation $j$} & $1980 \mathrm{~s}$ & 153.021 & 6.348 & 712.080 & 2.053 & 3662.771 & 32 \\
\hline & $1990 \mathrm{~s}$ & 6.553 & 4.691 & 4.043 & 1.631 & 15.855 & 15 \\
\hline
\end{tabular}




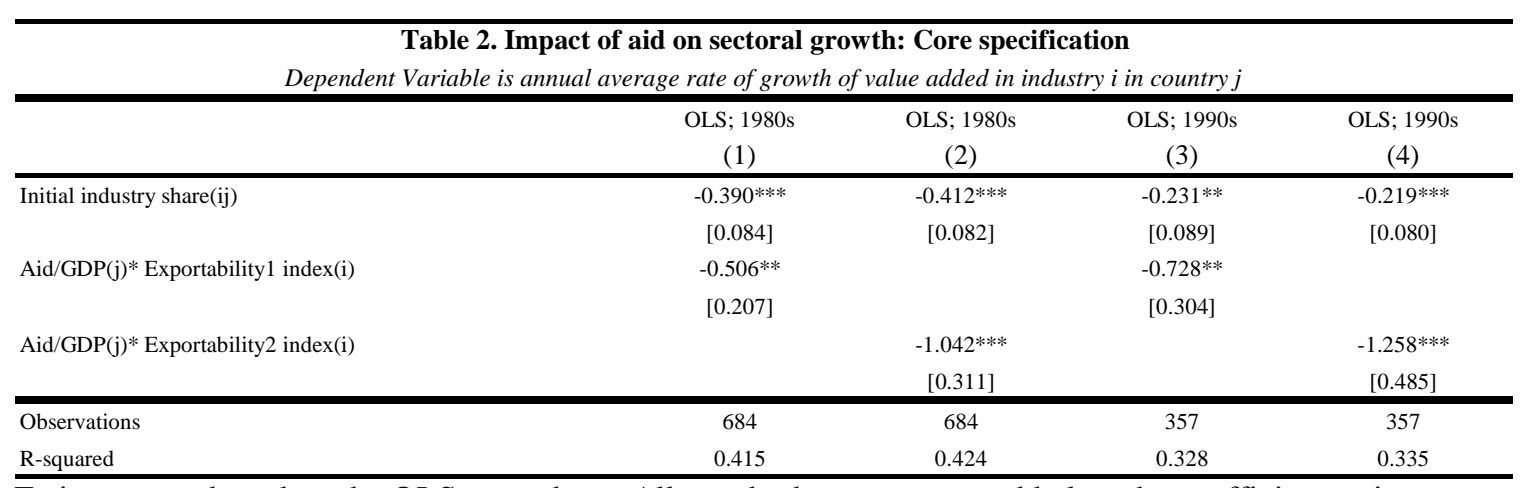

Estimates are based on the OLS procedure. All standard errors, reported below the coefficient estimates, are robust. $* * *, * *$, and $*$ denote significance at 1,5 , and 10 percent, respectively. All equations include country and industry fixed effects. Initial industry share (ij) refers to the share of industry $i$ in country $j$ as a share of total manufacturing sector value added in country $\mathrm{j}$. Aid/GDP ( $\mathrm{j}$ ) refers to the share of aid to GDP in country $\mathrm{j}$ averaged over the period. Exportability 1 index is a dummy that takes on a value of 1 if an industry's ratio of exports to value added is greater than the median value, and 0 otherwise. Exportability 2 index is a dummy that takes on a value of 1 for ISIC sectors 321-324, and 0 otherwise. 
Table 3. Impact of aid on sectoral growth: Robustness to instrumentation

Panel A: Dependent Variable is annual average rate of growth of value added in industry $i$ in country $j$

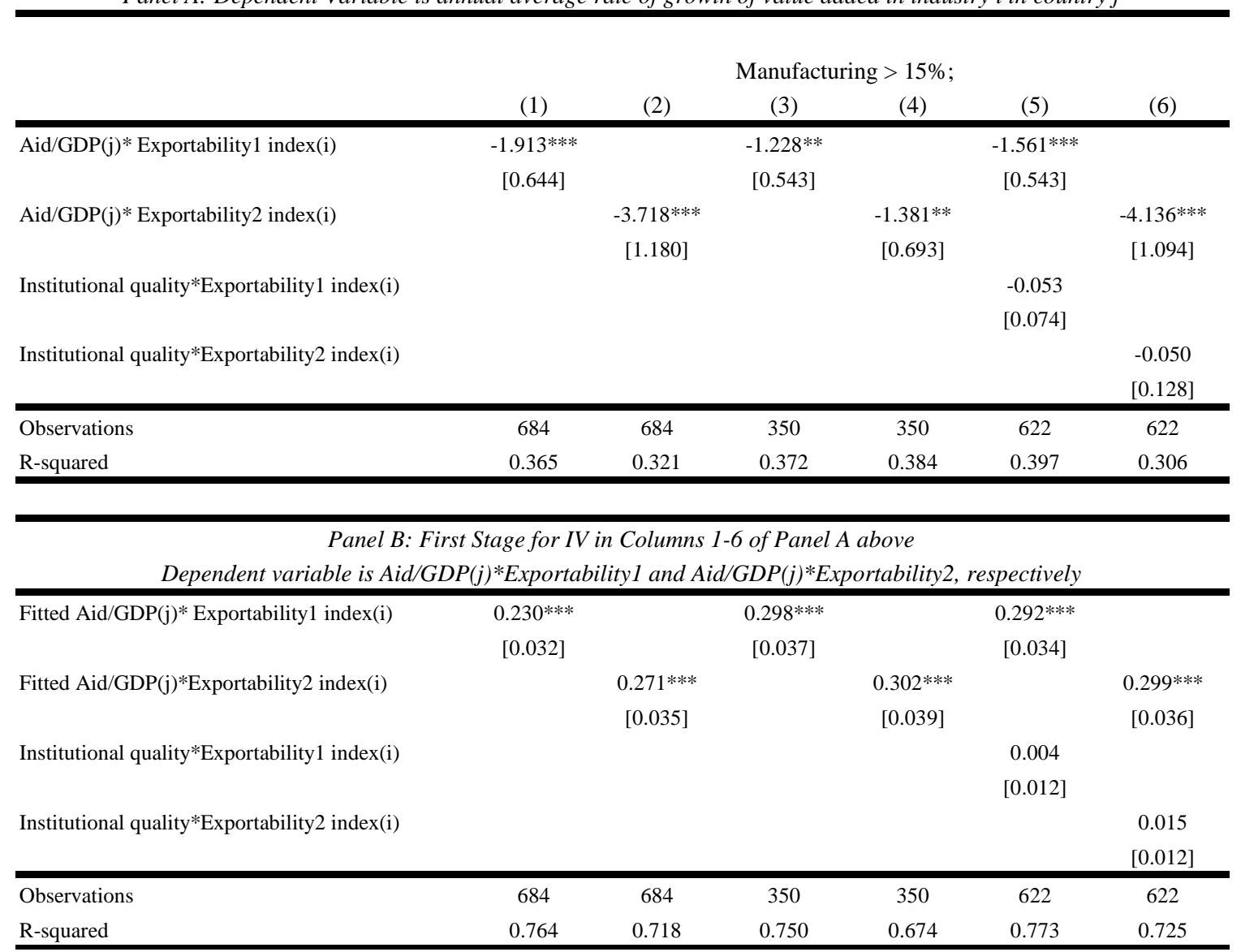

Estimates in this table use an instrumental variables (IV) procedure. Unless otherwise noted, all specifications are for the 1980s. All standard errors, reported below the coefficient estimates, are robust. ***, **, and * denote significance at 1, 5, and 10 percent, respectively. Standard errors are corrected, using the procedure in Frankel and Romer (1999), to allow for the fact that the instruments are estimated. All equations include country and industry fixed effects. Initial industry share (ij) refers to the share of industry $i$ in country $j$ as a share of total manufacturing sector value added in country $j$. Aid/GDP (j) refers to the share of aid to GDP in country $j$ averaged over the period. Exportability1 index is a dummy that takes on a value of 1 if an industry's ratio of exports to value added is greater than the median value, and 0 otherwise. Exportability 2 index is a dummy that takes on a value of 1 for ISIC sectors 321-324, and 0 otherwise. The specifications in columns 1, 2, 5 and 6 are based on the core sample, while those in columns 3 and 4 are based on a sample of countries whose manufacturing to GDP ratio exceeds 15 percent. In Panel B, the dependent variable (which is the endogenous regressor in Panel A) is the product of aid/GDP in country $\mathrm{j}$ times the relevant exportability index (i). Fitted aid is obtained from estimating a gravity-type model of bilateral aid flows as described in the Appendix. The institutional quality variable is from ICRGE (International Country Risk Guide) and is a measure of the quality of government institutions that affect property rights or the ability to conduct business. It is published by a private firm that provides consulting services to international investors. 
Table 4. Impact of Aid on sectoral growth: Is real exchange rate the channel?

\section{Dependent \\ variable is \\ excess- \\ appreciation $(j)$}

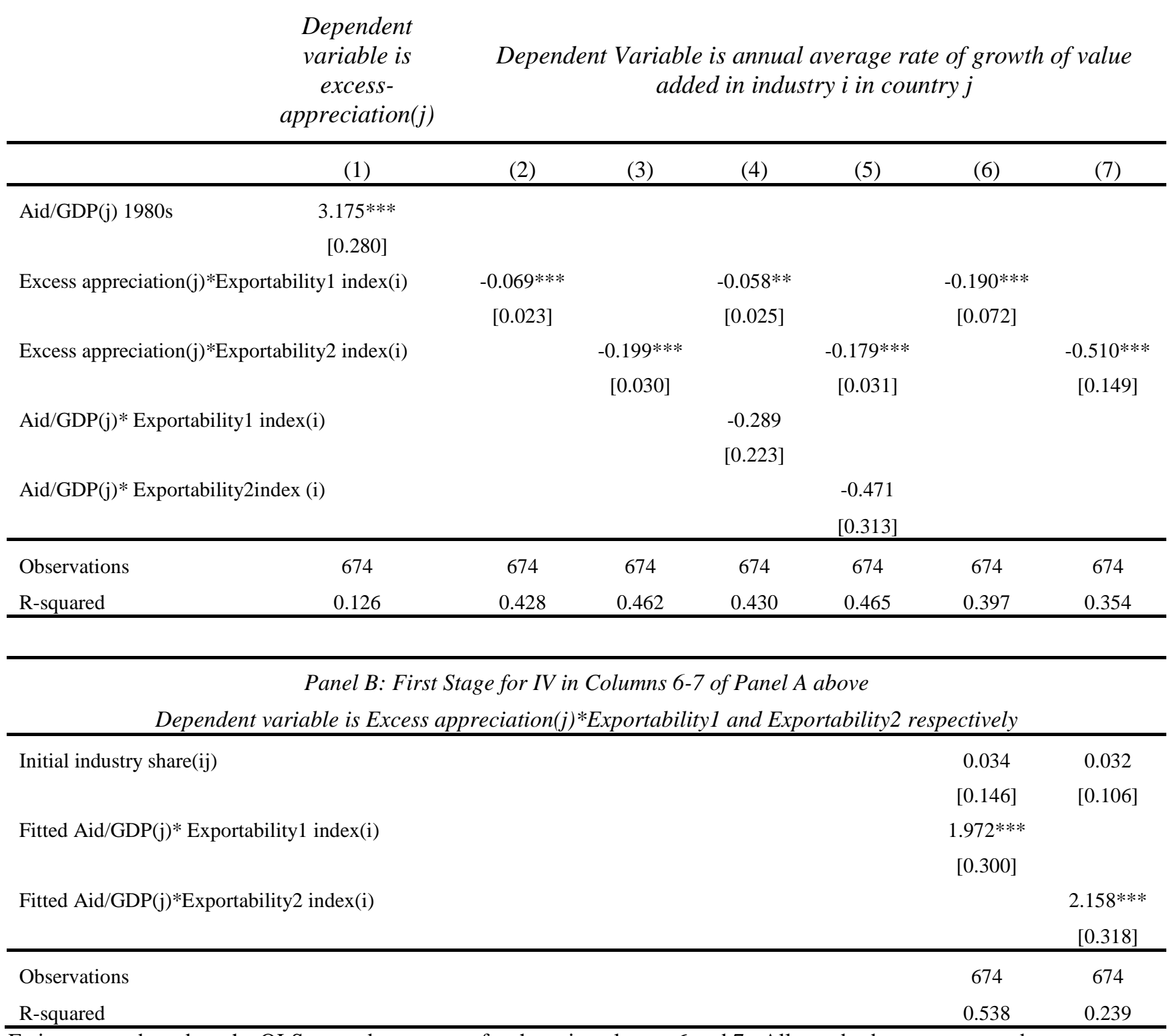

Estimates are based on the OLS procedure, except for those in columns 6 and 7. All standard errors, reported below the coefficient estimates, are robust. ***,**, and * denote significance at 1,5 , and 10 percent, respectively. All estimations except for column (1) include country and industry fixed effects and initial industry share (ij) of industry $\mathrm{i}$ in country $\mathrm{j}$ as a share of total manufacturing sector value added in country $\mathrm{j}$. Aid/GDP ( $j$ ) refers to the share of aid to GDP in country $j$ averaged over the period. Exportability 1 index is a dummy that takes on a value of 1 if an industry's ratio of exports to value added is greater than the median value and 0 otherwise. Exportability2 index is a dummy that takes on a value of 1 for ISIC sectors 321-324, and 0 otherwise. The excess appreciation variable is from Johnson, Ostry and Subramanian (2007). Note that the sample size is smaller than in the core specification because data on excess appreciation are not available for one country in the core specification. In columns 6 and 7, the instruments for excess appreciation are the same as those used for aid in Table 3. 
Table 5. Impact of aid on sectoral growth: Are there other channels?

Dependent Variable is annual average rate of growth of value added in industry $i$ in country $j$

\begin{tabular}{|c|c|c|c|c|c|}
\hline \multicolumn{6}{|c|}{ Panel A: Interacted with Exportabilityl index $(i)$} \\
\hline & (1) & (2) & (3) & (4) & $(5)$ \\
\hline Aid/GDP $(j) *$ Exportability 1 index(i) & $\begin{array}{c}- \\
0.547 * * * \\
{[0.205]}\end{array}$ & $\begin{array}{c}-0.368 * \\
{[0.217]}\end{array}$ & $\begin{array}{c}-0.560 * * \\
{[0.218]}\end{array}$ & $\begin{array}{c}-0.513 * * \\
{[0.207]}\end{array}$ & $\begin{array}{c}- \\
0.596 * * * \\
{[0.212]}\end{array}$ \\
\hline Policy $(\mathrm{j}) *$ Exportability 1 index(i) & $\begin{array}{l}-0.014 \\
{[0.024]}\end{array}$ & & & & \\
\hline Tariff*Exportability 1 index(i) & & $\begin{array}{c}0.001 * * \\
{[0.000]}\end{array}$ & & & \\
\hline Black Market Premium(j)*Exportability1 index(i) & & & $\begin{array}{c}-0.003 \\
{[0.008]}\end{array}$ & & \\
\hline Standard deviation of inflation*Exportability1 index(i) & & & & $\begin{array}{c}0.000 \\
{[0.000]}\end{array}$ & \\
\hline Aid/GDP(j)*Financial dependence(i) & & & & & $\begin{array}{c}0.316 \\
{[0.320]} \\
\end{array}$ \\
\hline Observations & 684 & 635 & 650 & 684 & 653 \\
\hline R-squared & 0.415 & 0.423 & 0.422 & 0.415 & 0.422 \\
\hline \multicolumn{6}{|c|}{ Panel B: Interacted with Exportability2 index(i) } \\
\hline Aid/GDP(j)* Exportability 2 index(i) & $\begin{array}{c}0.975 * * * \\
{[0.324]}\end{array}$ & $\begin{array}{c}0.818 * * \\
{[0.331]}\end{array}$ & $\begin{array}{c}1.034 * * * \\
{[0.318]}\end{array}$ & $\begin{array}{c}1.043 * * * \\
{[0.312]}\end{array}$ & $\begin{array}{c}1.030 * * * \\
{[0.320]}\end{array}$ \\
\hline Policy(j)*Exportability2 index(i) & $\begin{array}{c}0.023 \\
{[0.030]}\end{array}$ & & & & \\
\hline Tariff*Exportability2 index(i) & & $\begin{array}{c}0.002 * \\
{[0.001]}\end{array}$ & & & \\
\hline Black Market Premium(j)*Exportability2 index(i) & & & $\begin{array}{c}0.004 \\
{[0.007]}\end{array}$ & & \\
\hline Standard deviation of inflation*Exportability2 index(i) & & & & $\begin{array}{c}0.000 \\
{[0.000]}\end{array}$ & \\
\hline Aid/GDP(j)*Financial dependence(i) & & & & & $\begin{array}{c}0.109 \\
{[0.323]} \\
\end{array}$ \\
\hline Observations & 684 & 635 & 631 & 684 & 653 \\
\hline R-squared & 0.424 & 0.438 & 0.431 & 0.424 & 0.429 \\
\hline
\end{tabular}

Estimates are based on the OLS procedure. All standard errors, reported below the coefficient estimates, are robust. $* * *, * *$, and $*$ denote significance at 1,5 , and 10 percent, respectively. All equations include country and industry fixed effects and initial industry share (ij) of industry $\mathrm{i}$ in country $\mathrm{j}$ as a share of total manufacturing sector value added in country $\mathrm{j}$. Aid/GDP $(\mathrm{j}$ ) refers to the share of aid to GDP in country $\mathrm{j}$ averaged over the period. Exportability1 index is a dummy that takes on a value of 1 if an industry's ratio of exports to value added is greater than the median value, and 0 otherwise. Exportability 2 index is a dummy that takes on a value of 1 for ISIC sectors 321-324, and 0 otherwise. The policy variable is from Wacziarg and Welch (2003), the tariff variable from the World Bank, the black market premium variable from Reinhart and Rogoff (2004), the inflation variability variable from the IMF, and the financial dependence variable from Rajan and Zingales (1998) (see Appendix Table 1A for details). Note also that the sample varies between columns because of data availability for some variables. 


\section{Appendix 1. Main Data Sources and Description}

- Industrial Statistics Database (2003) of the United Nations Industrial Development Organization (UNIDO) for data on value added and labor share. Data are at 3-digit level of the International Standard Industrial Classification of All Economic Activities (ISIC, Revision 2). [UNIDO database].

- World Development Indicators (World Bank) for the data on the share of manufacturing and services in GDP.

- WITS (World Integrated Trade Solution) data (World Bank) for exportability index.

- OECD's Development Assistance Committee (DAC) for data on aid.

\section{Growth Rate of Real Value Added:}

The UNIDO dataset provides nominal value added both in terms of US dollars and local currency. The value added figure in US dollars is used for all regression analysis. The nominal value added (in current US dollars) was changed to a real value added (in constant Year 2000 US dollars), using the U.S. Producer Production Index provided by the International Monetary Fund's International Financial Statistics (IFS). This measure was, in turn, compared with the real value added in local currency to ascertain its reliability. ${ }^{16}$ More specifically, we required the correlation between the two be higher than 0.75 to be included in our base sample.

We then calculated the average annual growth rate of real value added for industry $i$ in country $j$, for the 1980s and 1990s. We calculated this wherever data existed for at least a seven-year period.

Countries with aid less than $1 \%$ of GDP are not included in the regression analysis because they included a number of emerging market and other countries such as Malta, Cyprus, and Kuwait that cannot be considered meaningful aid recipients. Peru is dropped from the base sample due to its unusually high level of growth rates in all industries in the UNIDO database (i.e. exceeds $100 \%$ in all sectors). Niger is dropped from the 1990s sample as the data contained an observation where the ratio of wages to value added exceeded 17. We also dropped observations when this ratio exceeded one (this resulted in 10 and 12 observations being dropped respectively from the sample for the 1980s and 1990s).

\footnotetext{
${ }^{16}$ Since local PPI was not available for all developing countries in IFS, alternative deflators needed to be used to construct the measure of real value added in local currency. Accordingly, whenever PPI was not available, we used the effective deflator constructed with the index of industrial production as in Rajan and Zingales (1998). This deflator is the ratio of the growth rate of nominal value added in the entire manufacturing sector (from the UNIDO database) to the growth rate of the index of industrial production (from IFS). Alternatively, a GDP deflator was used whenever these two series were not available.
} 
Appendix Table 1A. List of Variables and Data Source

\begin{tabular}{|c|c|c|}
\hline Variable Names & Description & Source \\
\hline $\begin{array}{l}\text { Growth Rate of Value } \\
\text { Added }_{i j}\end{array}$ & $\begin{array}{l}\text { Industry } i \text { 's annual growth rate of value added in } \\
\text { country } j \text {, averaged over each decade. }\end{array}$ & UNIDO (2003). \\
\hline $\begin{array}{l}\text { Initial Industry }_{\text {Share }_{i j}}\end{array}$ & $\begin{array}{l}\text { Industry } i \text { 's share in country } j \text { 's total manufacturing } \\
\text { value added at the beginning of the decade. }\end{array}$ & UNIDO (2003). \\
\hline Exportability1 index $_{i}$ & $\begin{array}{l}\text { A dummy that takes a value of } 1 \text { if industry } i \text { has a ratio } \\
\text { of exports to value that exceeds the industry median } \\
\text { value. For each industry, the average ratio of exports to } \\
\text { value added was calculated using a group of developing } \\
\text { countries. }\end{array}$ & $\begin{array}{l}\text { WITS data, World } \\
\text { Bank (at the 3-digit } \\
\text { ISIC code). }\end{array}$ \\
\hline${\text { Exportability2 } \text { index }_{i}}$ & $\begin{array}{l}\text { A dummy that takes a value of } 1 \text { for the four textiles } \\
\text { and leather industries (ISIC 321-324). }\end{array}$ & $\begin{array}{l}\text { WITS data, World } \\
\text { Bank (at the 3-digit } \\
\text { ISIC code). }\end{array}$ \\
\hline Excess Appreciation $j$ & $\begin{array}{l}\text { This measure is based on long-run PPP. For every year } \\
\text { in the sample period, we regressed a country's price } \\
\text { level of GDP from the Penn World Tables (6.1) on its } \\
\text { real GDP per capita (in PPP terms). The deviation of } \\
\text { the actual price level from the estimated price level is a } \\
\text { measure of the country's overvaluation. We averaged } \\
\text { the annual values over the 1980s and 1990s respectively } \\
\text { to obtain the final measure of overvaluation }\end{array}$ & $\begin{array}{l}\text { Johnson, Ostry and } \\
\text { Subramanian (2004). }\end{array}$ \\
\hline $\begin{array}{l}\text { Financial } \\
\text { Dependence }_{i}\end{array}$ & $\begin{array}{l}\text { The measure of external financial dependence for all } \\
\text { firms in industry } i \text { during the 1980s. }\end{array}$ & $\begin{array}{l}\text { Rajan and Zingales } \\
\text { (1998). }\end{array}$ \\
\hline Aid / GDP & The ratio of aid to GDP for country $j$. & OECD DAC database. \\
\hline Policy $_{j}$ & Percent of years that a country is considered open. & $\begin{array}{l}\text { Wacziarg and Welch } \\
(2003) .\end{array}$ \\
\hline Tariffs & $\begin{array}{l}\text { Unweighted average (across products) over years for } \\
\text { which data are available }\end{array}$ & $\begin{array}{l}\text { World Bank (website } \\
\text { described in footnote } \\
12 \text { in the text. }\end{array}$ \\
\hline $\begin{array}{l}\text { Black market } \\
\text { premium }_{j}\end{array}$ & $\begin{array}{l}\text { Percent difference between a country's parallel market } \\
\text { and official exchange rate expressed in terms of the } \\
\text { latter. }\end{array}$ & $\begin{array}{l}\text { Reinhart and Rogoff } \\
\text { (2004). }\end{array}$ \\
\hline Institutional quality $_{j}$ & $\begin{array}{l}\text { Several ICRGE indices averaged for the relevant } \\
\text { period. }\end{array}$ & $\begin{array}{l}\text { Bosworth and Collins } \\
(2003) \text {. }\end{array}$ \\
\hline Life expectancy $y_{j}$ & $\begin{array}{l}\text { Life expectancy at birth for beginning of the relevant } \\
\text { decade. }\end{array}$ & WDI \\
\hline Geography $_{j}$ & Average of number of frost days and tropical land area. & $\begin{array}{l}\text { Bosworth and Collins } \\
\text { (2003). }\end{array}$ \\
\hline
\end{tabular}

${ }^{17}$ The Trade and Production Database provides the WITS trade data at the 3 -digit ISIC code. This database is available at: www.worldbank.org/research/trade 


\begin{tabular}{|c|c|c|c|}
\hline \multicolumn{4}{|c|}{$\begin{array}{l}\text { Appendix Table 1B. Aid as a Percentage of GDP } \\
(* \text { denotes inclusion in core sample })\end{array}$} \\
\hline 1980s & & $1990 \mathrm{~s}$ & \\
\hline Malawi* & $17.56 \%$ & Tanzania* & $13.92 \%$ \\
\hline Burundi* & $14.90 \%$ & Ethiopia* & $10.83 \%$ \\
\hline Senegal* & $12.41 \%$ & Senegal* & $10.40 \%$ \\
\hline Tanzania* & $11.71 \%$ & Bolivia* & $7.88 \%$ \\
\hline Papua New Guinea* & $11.09 \%$ & Kenya* & $6.73 \%$ \\
\hline Zambia* & $10.72 \%$ & Jordan* & $6.32 \%$ \\
\hline Madagascar* & $8.67 \%$ & Cameroon* & $4.65 \%$ \\
\hline Sri Lanka* & $8.20 \%$ & Sri Lanka* & $3.57 \%$ \\
\hline Kenya* & $8.13 \%$ & Egypt* & $3.29 \%$ \\
\hline Swaziland* & $7.24 \%$ & Morocco* & $1.55 \%$ \\
\hline Honduras* & $6.48 \%$ & Philippines* & $1.37 \%$ \\
\hline Botswana* & $6.37 \%$ & Tunisia* & $1.32 \%$ \\
\hline Bolivia* & $6.15 \%$ & Mauritius* & $1.13 \%$ \\
\hline Bangladesh* & $5.91 \%$ & Indonesia* & $1.02 \%$ \\
\hline Congo* & $5.87 \%$ & Costa Rica & $0.94 \%$ \\
\hline Jamaica* & $5.68 \%$ & Panama & $0.81 \%$ \\
\hline Costa Rica* & $4.61 \%$ & Algeria & $0.64 \%$ \\
\hline Israel & $4.03 \%$ & India* & $0.56 \%$ \\
\hline Mauritius* & $3.59 \%$ & Russia & $0.46 \%$ \\
\hline Fiji* & $3.30 \%$ & Cyprus & $0.34 \%$ \\
\hline Jordan* & $3.15 \%$ & Uruguay & $0.29 \%$ \\
\hline Egypt* & $2.96 \%$ & Malaysia & $0.28 \%$ \\
\hline Cote d'Ivoire* & $2.77 \%$ & South Africa & $0.27 \%$ \\
\hline Pakistan* & $2.75 \%$ & Chile & $0.25 \%$ \\
\hline Cameroon* & $2.59 \%$ & Colombia & $0.24 \%$ \\
\hline Ghana* & $2.38 \%$ & Oman & $0.18 \%$ \\
\hline Tunisia* & $2.25 \%$ & Venezuela & $0.05 \%$ \\
\hline Morocco* & $2.14 \%$ & Korea & $0.04 \%$ \\
\hline Philippines* & $1.86 \%$ & Singapore & $0.03 \%$ \\
\hline Guatemala* & $1.48 \%$ & Kuwait & $0.02 \%$ \\
\hline Indonesia* & $1.17 \%$ & China (Hong Kong) & $0.02 \%$ \\
\hline Thailand* & $1.01 \%$ & & \\
\hline Malta & $0.99 \%$ & & \\
\hline Panama & $0.99 \%$ & & \\
\hline Cyprus & $0.92 \%$ & & \\
\hline India* & $0.76 \%$ & & \\
\hline Barbados & $0.73 \%$ & & \\
\hline Uruguay & $0.37 \%$ & & \\
\hline Algeria & $0.33 \%$ & & \\
\hline Chile & $0.32 \%$ & & \\
\hline Colombia & $0.30 \%$ & & \\
\hline Bahamas & $0.19 \%$ & & \\
\hline Singapore & $0.16 \%$ & & \\
\hline Korea & $0.08 \%$ & & \\
\hline Venezuela & $0.07 \%$ & & \\
\hline Iran & $0.06 \%$ & & \\
\hline Kuwait & $0.03 \%$ & & \\
\hline
\end{tabular}




\section{Appendix Table 1C. Description of ISIC 3-digit Industries}

$\begin{array}{lcc}\text { ISIC } & \text { Industrial sectors } & \text { Exportability1 } \\ \text { code } & \text { Index } & \text { Exportability2 } \\ \text { Index }\end{array}$

\begin{tabular}{llll}
\hline 311 & Food products & 1 & 0 \\
313 & Beverages & 0 & 0 \\
314 & Tobacco & 0 & 0 \\
321 & Textiles & 1 & 1 \\
322 & Wearing apparel, except footwear & 1 & 1 \\
323 & Leather products & 1 & 1 \\
324 & Footwear, except rubber or plastic & 1 & 1 \\
331 & Wood products, except furniture & 1 & 0 \\
332 & Furniture, except metal & 0 & 0 \\
341 & Paper and paper products & 0 & 0 \\
342 & Printing and publishing & 0 & 0 \\
351 & Industrial chemicals & 1 & 0 \\
352 & Other chemicals & 0 & 0 \\
353 & Petroleum refineries & 1 & 0 \\
354 & Misc. petroleum and coal products & 1 & 0 \\
355 & Rubber products & 0 & 0 \\
356 & Plastic products & 0 & 0 \\
361 & Pottery, china, earthenware & 0 & 0 \\
362 & Glass and glass products & 0 & 0 \\
369 & Other non-metallic mineral products & 0 & 0 \\
371 & Iron and steel & 0 & 0 \\
372 & Non-ferrous metals & 1 & 0 \\
381 & Fabricated metal products & 0 & 0 \\
382 & Machinery, except electrical & 1 & 0 \\
383 & Machinery, electrical & 0 & 0 \\
384 & Transport equipment & 1 & 0 \\
385 & Professional and scientific equipment & 1 & 0 \\
390 & Other manufactured products & 1 & \\
\hline & & & 0
\end{tabular}

Appendix Table 1D: Is the Core Sample Representative?

\begin{tabular}{|l|l|l|}
\hline \multicolumn{1}{|c|}{ Variable } & $\begin{array}{c}\text { Sample in } \\
\text { this paper }\end{array}$ & Larger sample \\
\hline Aid to GDP & & \\
$\quad$ Mean & $5.3 \%$ & $7.0 \%$ \\
Standard deviation & $3.9 \%$ & $5.6 \%$ \\
\hline Real GDP growth & & \\
$\quad$ Mean & $1.0 \%$ & $0.7 \%$ \\
Standard deviation & $2.3 \%$ & $2.1 \%$ \\
\hline Real value added growth in & & \\
manufacturing & & \\
Mean & $4.8 \%$ & $3.6 \%$ \\
Standard deviation & $3.5 \%$ & $3.6 \%$ \\
\hline
\end{tabular}

Core sample comprises the 32 countries for which UNIDO's disaggregate manufacturing data are available and that have aid to GDP less than 1 percent or fall in the category of low-income countries. Larger sample includes countries that satisfy the same criteria but for which data on aggregate manufacturing is available in the World Bank's World Development Indicators (it excludes 3 countries with an aid-to-GDP ratio exceeding 30 percent). 


\section{References}

Acemoglu, Daron, Simon Johnson, James A. Robinson, and Yunyong Thaicharoen, 2003, "Institutional Causes, Macroeconomic Symptoms: Volatility, Crises and Growth," Journal of Monetary Economics, No. 50, pp. 49-123.

Adam, Christopher, 2005, "Exogenous Inflows and Real Exchange Rates: Theoretical Quirk or Empirical Reality?" Peter Isard, Leslie Lipschitz, Alexandros Mourmouras, Boriana Yontcheva, (eds.), The Macroeconomic Management Of Foreign Aid, (Washington: International Monetary Fund).

Adam, Christopher, and Stephen A. O'Connell, 1999, "Aid, Taxation and Development in Sub Saharan Africa," Economics and Politics, Vol. 11, November, pp. 225-53.

Alesina, Alberto and David Dollar, 2000, "Who Gives Foreign Aid to Whom and Why?" Journal of Economic Growth, Vol. 5, No. 1, pp. 33-63.

Alesina, Alberto, and Beatrice Weder, 2002, "Do Corrupt Governments Receive Less Foreign Aid?" American Economic Review, Vol. 92, No. 4, pp. 1126-37.

Arellano, C., A. Bulir, T. Lane, L. Lipschitz, 2005, “The Dynamic Implications of Foreign Aid and Its Variability," IMF Working Paper 05/119, Washington: International Monetary Fund.

Atingi-Ego, Michael, and Rachel Sebudde, 2000, "Uganda's Equilibrium Real Exchange Rate and its Implications for Non-Traditional Export Performance," Bank of Uganda Staff Papers, Vol. 2, No. 1, pp. 1-43.

Azam, Jean-Paul, Shantayanan Devarajan, and Stephen A. O'Connell, 1999, "Aid Dependence Reconsidered," World Bank Policy Research Working Paper No. 2144.

Banerjee, Abhijit, Shawn Cole, Esther Duflo, and Leigh Linden, 2004, "Remedying Education: Evidence from two randomized experiments in India," Mimeo, MIT.

Banerjee, Abhijit and Lakshmi Iyer, 2005, "History, Institutions, and Economic performance: The Legacy of Colonial Land Tenure Systems in India," American Economic Review, pp. 1190-1213.

Barro, Robert J., and Jong-Wha Lee, 2004, "IMF Programs: Who is Chosen and What are the Effects?" mimeo.

Bauer, P.T., 1971, Dissent on Development: Studies and Debates in Development Economics, London: Weidenfeld \& Nicholson.

Berg, A., M. Hussain, S. Aiyar, S. Roache, and A. Mahone, 2005, "The Macroeconomics of Managing Increased Aid Inflows: Experiences of Low-Income Countries and Policy Implications,"'(Washington: International Monetary Fund) 
Bhagwati, Jagdish, and Padma Dasai, 1970, Planning for Industrialization, London: Oxford University Press.

Brautigam and Knack, 2004, "Foreign Aid, Institutions, and Governance in Sub-Saharan Africa," Economic Development and Cultural Change, pp. 255-85.

Bulir, A. and T.Lane, 2002, “Aid and Fiscal Management," IMF Working Paper 02/112.

Burnside, Craig and David Dollar (2000) "Aid, Policies, and Growth," American Economic Review No. 90 Vol. 4, pp. 847-68.

Clemens, Michael A., Steven Radelet and Rikhil Bhavnani, 2004, "Counting Chickens when They Hatch: The Short Term Effect of Aid on Growth," Working Paper No. 44, Center for Global Development.

Cordon and Neary, 1982, "Booming Sector and De-Industrialization in a Small Open Economy," Economic Journal, December, Vol. 92, No. 368, pp. 825-48.

Collier, Paul, and David Dollar, 2002,"Aid Allocation and Poverty Reduction," European Economic Review, Vol. 46, No. 8, pp. 1475-1500.

Dalgaard, Carl-Johan, Henrik Hansen and Finn Tarp, 2004, "On the Empirics of Foreign Aid and Growth,” Economic Journal, Vol. 114, No. 496, pp.191-216.

Dollar, D., 1992, “Outward-oriented developing economies really do grow more rapidly: evidence from 95 LCDs, 1976-1985," Economic Development and Cultural Change, Vol. 40, pp. 523-44.

Easterly, William, 2003, “Can Foreign Aid Buy Growth?” Journal of Economic Perspectives, Vol. 17, No. 3, pp. 23-48.

Easterly, William, and Ross Levine, 2003, "Tropics, Germs, and Crops: How Endowments Influence Economic Development," Journal of Monetary Economics, Vol. 50, No. 1, pp. 3-39.

Easterly, William, Ross Levine, and David Roodman, 2004, "New Data, New Doubts: A Comment on Burnside and Dollar's Aid, Policies, and Growth," American Economic Review, forthcoming.

Elbadawi, I. A., 1999, "External Aid: Help or Hindrance to Export Orientation in Africa?" Journal of African Economics, Vol. 8, December, pp. 578-616.

Frankel, Jeffrey, 2004, "On the Yuan: The Choice between Adjustment under a Fixed Exchange Rate and the Adjustment under Flexible Rate," CESifo Economic Studies, Gerhard Illing (ed.).

Frankel, Jeffery, and David Romer, 1999, “Does Trade Cause Growth?” American Economic Review, Vol. 89, No. 3, pp. 379-99. 
Friedman, Milton, 1958, “Foreign Economic Aid,” Yale Review, Vol. 47, No. 4, pp. 501-16.

Hansen, Henrik, and Finn Tarp, 2001, “Aid and Growth Regressions," Journal of Development Economics, Vol. 64. pp. 547-70.

Johnson, Simon, Jonathan Ostry, and Arvind Subramanian, 2007, "Prospects for Africa: Benchmarking the Contsraints," International Monetary Fund Working Paper 07/52, Washington D.C.

Jones, Benjamin, and Benjamin Olken, 2005, “The Anatomy of Start-Stop Growth,” NBER Working paper, No. 11528.

Knack, S., 2001, "Aid Dependence and the Quality of Governance: Cross-Country and Empirical Test," Southern Economic Journal, pp. 310-329.

Kremer, Michael, Edward Miguel, and Rebecca Thornton, 2004, "Incentives to Learn," NBER Working Paper No. W10971.

Krugman, P.R., 1987, "The Narrow Moving Band, the Dutch Disease, and the Economic Consequences of Mrs. Thatcher," Journal of Development Economics.

Krueger, A.O., 1975, The Benefits and Costs of Import Substitution in India: A Microeconomic Study (Minneapolis: University of Minnesota Press).

Nicita, Alessandro, and Marcelo Olarreaga, 2001, "Trade and Production, 1976-99," Policy Research Working Paper Series 2701, (Washington: The World Bank.).

Nyoni, Timothy, 1998, "Foreign Aid and Economic Performance in Tanzania," World Development, Vol. 26, No. 7, pp. 1235-40.

Prati, Alessandro, and Thiessy Tressel, 2006, "Aid Volatility and Dutch Disease. Is There a role for Macroeconomic Policies?" mimeo, (Washington: International Monetary Fund).

Rajan, Raghuram, and Arvind Subramanian, 2008, "Aid and Growth: What Does the CrossCountry Evidence Really Show?" Review of Economics and Statistics, Vol. 90, No. 4, pp.643-665.

Rajan, Raghuram, and Luigi Zingales, 1998, "Financial Dependence and Growth," American Economic Review, Vol. 88, No. 3, pp.559-86.

Reinhart, Carmen, and Kenneth Rogoff, 2004, "The Modern History of Exchange Rate Arrangements," Quarterly Journal of Economics, Vol.119, No. 1, pp. 1-48.

Rodriguez, Francisco and Dani Rodrik, 1997, "Trade Policy and Economic Growth: A Skeptic's Guide to the Cross-National Evidence," in Ben Bernanke and Kenneth Rogoff (eds.) NBER Macroeconomics Manual, 2000. 
Rodrik, Dani, 2007, “The Real Exchange Rate and Economic Growth: Theory and Evidence," Kennedy School of Government manuscript.

Roodman, David, 2004, “The Anarchy of Numbers: Aid, Development, and Cross-country Empirics," (Washington: Center for Global Development).

Staiger, Douglas, and James Stock (1997) "Instrumental Variables Regression with Weak Instruments," Econometrica, No. 65 Vol. 3; pp. 557-86.

Subramanian, Arvind, and Utsav Kumar, 2006, "Counting Chickens before they Hatch: A Comment," mimeo, (Washington: International Monetary Fund).

Svensson, Jakob, 2003, "Why Conditional Aid Doesn't Work and What Can Be Done About It?" Journal of Development Economics, Vol. 70, No. 2, pp. 381-402.

Torvik, Ragnar, 2001, "Learning by doing and the Dutch disease," European Economic Review, vol. 45(2), pages 285-306.

United Nations Industrial Development Organization, 2003, Database on Industrial Statistics, United Nations, Vienna.

Van Wijnbergen, Sweder, 1985, “Aid, Export promotion and the Real Exchange Rate: An African Dilemma?” Center for Economic Policy Research Paper No. 88.

Van Wijnbergen, Sweder, 1986, "Macroeconomic Aspects of the effectiveness of Aid: On the Two-Gap Model, Home Goods Disequilibrium, and Real Exchange Rate Misalignment," Journal of International Economics, Vol. 21, No. 1-2, pp 123-36.

Vos, Rob, 1998, "Aid Flows and Dutch Disease in a general Equilibrium Framework for Pakistan," Journal of Policy Modelling, Vol. 20, No. 1, pp. 77-109.

World Bank, 2004, "Making Services Work for Poor People,” World Development Report:

World Bank, 1998, “Knowledge for Development,” World Development Report

Yano, Makoto, and Jeffrey B. Nugent, 1999, “Aid, Nontraded Goods, and the Transfer Paradox in Small Countries," The American Economic Review, Vol. 89, No.3, pp. 431-49.

Younger, Stephen, 1992, "Aid and Dutch Disease: Macroeconomic Management When Everybody Loves You," World Development, Vol. 20, No. 11, pp. 1587-97. 


\section{Appendix: Instrumentation Strategy}

Our instruments for aid are based on Rajan and Subramanian (2008). The key idea there is to model the supply of aid based on donor and donor-recipient relationships rather than on recipient-specific characteristics. In other words, we base our instrument on considerations that drive individual donors to give aid to a country other than those related to a country's level of income or growth. So, our construction of instruments starts from the bilateral (donor-recipient) relationship and aggregates up (as Frankel and Romer (1999) have done in the trade literature).

We posit that donors lend for reasons of history and in order to have influence. The greater the extent of historic relationships between a donor and a recipient the more likely that a donor will want to give aid. We capture historic relationships through colonial links and commonality of language.

One way to proxy for influence is through the relative size of donor and recipient. The bigger the donor is relative to the recipient, the more influence the donor is likely to have, so the ratio of the donor population to that of the recipient could be a good proxy for influence. In addition, a donor's influence is likely to be particularly pronounced if it is relatively large when it has close links with the recipient (so that it not only understands the pathways of influence but also potentially scares away other donors from seeking influence). We capture this channel by including the interaction between relative size and colonial links.

An example should help fix ideas; the United Kingdom should be willing to give more aid per capita to Uganda than to India; but it will be more willing to give aid to Uganda than to a similar-sized country in Africa, say Senegal, because France is likely to have a significant aid presence in the latter, thus diluting any possibility of British influence.

The aid supply decision from a donor (d) to a recipient (r) can be expressed by the following model:

$$
\begin{aligned}
& A_{d r t} / \mathrm{GDP}_{r t}=\beta_{1}{ }^{\prime} Y_{d r t}+v_{d r t} \\
& =\beta_{0}+\beta_{1} \mathrm{COMLANG}_{d r}+\beta_{2} \mathrm{CURCOL}_{d r}+\beta_{3} \mathrm{COMCOL}_{d r}+\beta_{4} \text { COMCOLUK }_{d r}+\beta_{5} \text { COMCOLFRA }_{d r} \\
& +\beta_{6} \text { COMCOLSPA } \\
& +\beta_{7} \mathrm{COMCOLPOR}_{d r}+\beta_{8} \log \left(\mathrm{POP}_{d} / \mathrm{POP}_{r}\right) \\
& +\beta_{9} \log \left(\mathrm{POP}_{d} / \mathrm{POP}_{r}\right) * \mathrm{COMCOL}_{d r}+\beta_{10} \log \left(\mathrm{POP}_{d} / \mathrm{POP}_{r}\right) * \mathrm{COMCOLUK}_{d r} \\
& +\beta_{11} \log \left(\mathrm{POP}_{d} / \mathrm{POP}_{r}\right) * \mathrm{COMCOLFRA}_{d r}+\beta_{12} \log \left(\mathrm{POP}_{d} / \mathrm{POP}_{r}\right) * \mathrm{COMCOLSPA}_{d r} \\
& +\beta_{13} \log \left(\mathrm{POP}_{d} / \mathrm{POP}_{r}\right) * \mathrm{COMCOLPOR}_{d r}+v_{d r t}
\end{aligned}
$$

where $A_{d r t}$ is the aid given by donor d to recipient $\mathrm{r}$ in time period t. GDP $\mathrm{rt}_{\mathrm{rt}}$ is the recipient country's GDP. The first three RHS variables capture historic factors: COMLANG is a dummy that takes a value of one if the donor and recipient share a common language; CURCOL is a dummy that takes a value of one if the recipient is currently a colony of the donor. COMCOL is a dummy that takes a value of one if the recipient was ever a colony of the donor. The next four variables simply disaggregate the colonial variable to capture difference across donors in the susceptibility of their giving to colonial ties (COMCOLUK, 
COMCOLFRA, COMCOLSPA, and COMCOLPOR refer in turn to colonial relationships involving respectively France, Portugal, Spain, and the United Kingdom).

The next set of variables relate to relative size. Donor size relative to the recipient is measured by the ratio of the logarithm of the populations of donor and recipient $\left(\log \left(P O P_{d} / P O P_{r}\right)\right)^{18}$. Donor influence relative to other donors is additionally measured by the interaction of the relative population size and the colonial dummy $\left(\log \left(\mathrm{POP}_{d} / \mathrm{POP}_{r}\right) * \mathrm{COMCOL}_{d r}\right)$.

The estimated equation is then aggregated across donors to yield a level of the fitted value of aid-to-GDP for the recipient for that period.

$$
\left(\bar{A}_{r t} / G D P_{r t}\right)=\sum_{d} \boldsymbol{\beta}_{1}^{\prime} Y_{d r t}
$$

In Rajan and Subramanian (2008), we present estimates for the model in (1) and show that they yield meaningful results. In Table 3 of Rajan and Subramanian (2008), we present estimates for the model in (1). Virtually all the instrumenting variables are significant for all the time horizons, and between them the variables account for a reasonable share (between 33 and 42 percent) of the variation in the donor allocation decision. All the colonial relationships are significant as are the two measures of influence. The larger the donor relative to the recipient, the greater the aid given; and this effect is magnified, as conjectured, in cases where the donor had a colonial relationship with the recipient. For example, for the period 1960-00, a 1 percent increase in the ratio of donor size relative to recipient is associated with a 0.1 percent increase in the ratio of aid to GDP given by the average donor, an amount which is increased by 0.2 percent for a U.K. colony (which is the sum of 0.6 percent for the average colony minus 0.4 percent for the U.K. colony dummy), 1 percent for a Spanish colony; 1.9 percent for a French colony and 3.3 percent for a Portuguese colony. Thus, influence seems to matter a lot for donors, especially for Portugal and France.

A few caveats are worth noting about this instrumentation strategy which is not perfect. It is possible that equation (1) does not apply equally to all donor-recipient pairs. Our claim here is not to explain fully the aid allocation decision but to extract some (hopefully exogenous) information from that decision that would be reasonable for instrumentation. We would note that since our regressions are all cross-sectional, additional complications from the time series aspects of aid are not introduced. Finally, it should be noted that we do use a countryspecific variable - namely population size - for instrumentation that might raise questions in terms of satisfying the exclusion restriction.

\footnotetext{
${ }^{18}$ To minimize endogeneity-related problems, we use the initial rather than the contemporaneous value of population.
} 